\title{
First record of Anastrepha obliqua (Diptera: Tephritidae) and a tritrophic relation with parasitoids in a citrus orchard in Pará state, Brazil
}

\author{
Marlon Gonçalves RODRIGUES ${ }^{1}$, Maria Gisely CAMARGOS2* (), Clarice Diniz ALVARENGA², Rosana \\ Cardoso Rodrigues da SILVA ${ }^{1}$, Álvaro Remígio AYRES ${ }^{1}$ \\ 1 Instituto Federal do Pará, BR 316, Km 61, Saudade II, PA, Brazil \\ 2 Universidade Estadual de Montes Claros, Department of Agricultural Sciences, Rua Reinaldo Viana 2630, 39440-000 Janaúba, MG, Brazil \\ *Corresponding author: mariagisely@hotmail.com; (D) https://orcid.org/0000-0002-8897-0604
}

\section{ABSTRACT}

Citriculture is a growing industry in Pará state, Brazil, but information regarding fruit flies and their associated parasitoids in this region is lacking. To address this gap in knowledge, we collected oranges (Citrus sinensis), lime oranges (C. sinensis), common sweet limes (C. limettioides), citrons (C. medica) and mandarins (C. reticulata). We recorded field infestation by Anastrepha obliqua in $C$. sinensis under natural conditions for the first time in the study region, and a tritrophic relationship between $C$. sinensis, A. obliqua, and the parasitoids Opius bellus and Asobara anastrephae was identified.

KEYWORDS: Citrus sinensis, Braconidae, eastern Amazon

\section{Primeiro registro de Anastrepha obliqua (Diptera: Tephritidae) e de uma relação tritrófica com parasitoides em um pomar de citros no estado do Pará, Brasil}

\section{RESUMO}

A citricultura está crescendo no Estado do Pará, Brasil, mas faltam informaçôes sobre as pragas conhecidas como moscas-dasfrutas e os parasitoides associados na região. Visando abordar esta lacuna no conhecimento, foram coletados frutos de laranja (Citrus sinensis), laranja var. lima (C. sinensis), lima-da-pérsia (C. limettioides), limão-cidra (C. medica) e tangerina (C. reticulata). Registramos, pela primeira vez, infestação em condições naturais de campo por Anastrepha obliqua em $C$. sinensis no Pará e identificamos uma tritrófica entre $C$. sinensis, A. obliqua e os parasitoides Opius bellus e Asobara anastrephae .

PALAVRAS-ChaVE: Citrus sinensis, Braconidae, Amazônia Oriental

Pará state is the seventh fruit-producing region in Brazil, with $1.64 \%$ of the country's production, constituting one of the largest citrus-producing areas in northern Brazil (Anuário Brasileiro de Fruticultura 2018; IBGE 2019). Citriculture is economically important for the state, and fruit fly infestations, especially by Anastrepha species, have been reported (Lemos et al. 2011a; Castilho 2013). Fruit flies are considered key pests, and, in most producing regions around the world, sweet oranges and mandarins are highly susceptible to fruit fly infestation (Raga et al. 2004; Raga and Galdino 2017). In Brazil, the most important fruit flies belong to the genera Anastrepha, Bactrocera, and Ceratitis. Ceratitis capitata (Wiedemann) and Anastrepha fraterculus (Wiedemann) are the two main citrus pests in the southeastern state of São Paulo
(Raga et al. 2004). In Pará, C. capitata have been recorded in mandarin (Citrus reticulata Blanco) and Anastrepha serpentina (Wiedemann) in $C$. reticulata from Tomé-Açu and Citrus sinensis (L.) Osbeck from Belém (Lemos et al. 2011b).

Biological control is a promising option for fruit fly control. Natural biological control, focusing on the conservation of natural enemies, is crucial in pest management programs, as these organisms are responsible for natural mortality in agroecosystems and maintenance of the pest balance level (Parra et al. 2002). Thus, the identification of potential native agents to control pests in producing regions is vital. The purpose of this study was therefore to identify citrus-infesting fruit flies and their associated parasitoids on small family farms in four municipalities in Pará. 
Citrus fruits were collected during irregular visits to four municipalities in northeastern Pará, Capitão Poço, Irituia, Mãe do Rio and Aurora do Pará (Figure 1, Table 1) between January 2018 and January 2019. We collected fruits without larval exit holes and no visible damage from trees and/or on the ground. Sample sizes varied according to fruit availability at the time of the visit. The fruits were transported to the laboratory, where they were counted, weighed, and organized in plastic trays on a thin layer of sterile sand. Fruit fly and/or parasitoid larvae and pupae were quantified per fruit and kept in individualized containers until adult emergence.

Anastrepha species were identified according to the taxonomic keys of Zucchi et al. (2011b), and parasitoids were identified according to the taxonomic keys of Canal and Zucchi (2000) and Marinho et al. (2011). The voucher specimens of the new associations of hosts and parasitoids were deposited in the entomological collection of Museu de Entomologia Luiz de Queiroz - MELQ (Universidade de São Paulo, campus Escola Superior de Agricultura Luiz de Queiroz - ESALQ) (Table 1).

Overall, 522 fruits were collected, with a combined weight of $57.3 \mathrm{~kg}$, among oranges (Citrus sinensis), lime oranges (C. sinensis), common sweet limes (Citrus limettioides Tanaka), citrons (Citrus medica L.), and mandarins (Citrus reticulata) (Table 1). We obtained 274 puparia from which 95 insects emerged, $78.9 \%$ of which were fruit flies and $21 \%$, parasitoids (Table 1). Most puparia (62.4\%) were obtained from oranges, with infestation rates of 2.3 puparia per fruit and 12.6 puparia $\mathrm{kg}^{-1}$ of fruit. The only citrus species free of infestation was citron.
Two fruit fly species were identified: $A$. serpentina and Anastrepha obliqua (Macquart). Three females were damaged and therefore the species could not be confirmed (Table 1). Anastrepha obliqua was collected only from oranges in Irituia, and this is the first record of A. obliqua in oranges in Pará. Irituia was also the only locality where parasitoids were found. Two Braconidae parasitoid species were identified as Opius bellus (Gahan) and Asobara anastrephae (Muesebeck) (Table 1). No puparia were found in fruits from Aurora do Pará.

Anastrepha serpentina occurs in 20 Brazilian states and is associated with 23 hosts, while $A$. obliqua is associated with 51 hosts across the country. In Brazil, oranges were reported to be infested by $A$. serpentina, A. obliqua, A. fraterculus, A. striata Schiner, A. turpiniae Stone, and C. capitata, and mandarins by $A$. serpentina, A. fraterculus, and C. capitata (Zucchi and Moraes 2008). In the Amazon region, A. obliqua is distributed in all states, infesting 25 hosts, but no record in Citrus had been reported (Zucchi et al 2011a). Anastrepha serpentina has only been registered in the Amazonian state Tocantins (Zucchi and Moraes 2008; Zucchi et al 2011a ).

In Pará, 23 fruit fly species have been registered, 22 belonging to Anastrepha and C. capitata (Zucchi and Moraes 2008). The species with the widest distribution in the state are $A$. striata, A. obliqua, A. distincta Greene, and $A$. serpentina (Lemos et al. 2011a). Anastrepha serpentina has been reported in oranges (in the municipalities of Belém and Capitão Poço) and mandarins (Tomé-Açu) (Lemos et al. 2011b), and $A$. obliqua in Barbados cherries (Malpighia punicifolia L.), guavas (Psidium guajava L.), jambos (Syzygium jambos (L.) Alston), araçá-boi (Eugenia stipitata McVaugh), Surinam cherries (Eugenia uniflora L.), starfruit (Averrhoa carambola L.), yellow

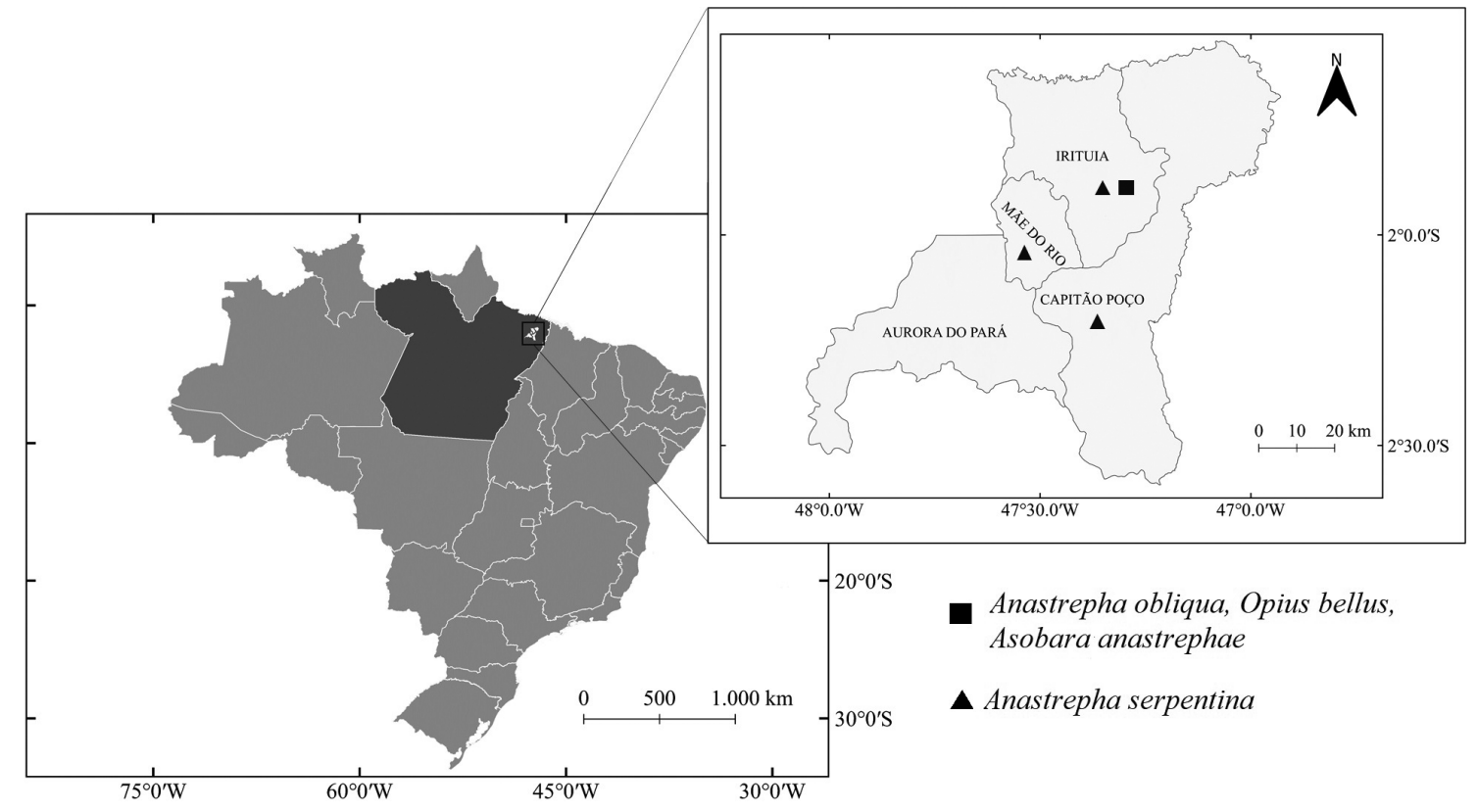

Figure 1. Location records of Anastrepha fruit flies and parasitoids in citrus orchards in eastern Pará state, northern Brazil. 
Table 1. Fruit flies and their parasitoids in citrus fruits from four municipalities in northeastern Pará state, Brazil, collected between January 2018 and January 2019.

\begin{tabular}{|c|c|c|c|c|c|c|c|c|c|c|c|}
\hline \multirow[b]{2}{*}{ Municipalities } & \multirow[b]{2}{*}{ Coordinates } & \multirow[b]{2}{*}{ Hosts } & \multirow[b]{2}{*}{$\begin{array}{l}\text { Fruit } \\
\text { (n) }\end{array}$} & \multirow[b]{2}{*}{$\begin{array}{l}\text { Weight } \\
(\mathrm{kg})\end{array}$} & \multirow[b]{2}{*}{$\begin{array}{l}\text { Pupae } \\
\text { (n) }\end{array}$} & \multicolumn{2}{|c|}{ Infestation } & \multicolumn{2}{|c|}{ Flies (n) } & \multirow[b]{2}{*}{$\begin{array}{l}\text { Fruit fly species } \\
\text { [voucher number] }\end{array}$} & \multirow{2}{*}{$\begin{array}{l}\text { Parasitoids ( } \mathrm{n} \text { ) } \\
\text { [voucher number] }\end{array}$} \\
\hline & & & & & & $\begin{array}{l}\text { Puparia/ } \\
\text { fruit }\end{array}$ & $\begin{array}{c}\text { Puparia/ } \\
\text { kg }\end{array}$ & Male & Female & & \\
\hline \multirow[t]{4}{*}{ Capitão Poço } & $\begin{array}{l}02^{\circ} 05^{\prime} 49.5^{\prime \prime} \mathrm{S}, \\
047^{\circ} 22^{\prime} 40.7^{\prime \prime} \mathrm{W}\end{array}$ & Citrus sinensis & 56 & 9.60 & 75 & 1.33 & 7.80 & 11 & 19 & Anastrepha serpentina & \\
\hline & & $\begin{array}{l}\text { Citrus sinensis (var. } \\
\text { lime orange) }\end{array}$ & 10 & 1.69 & 15 & 1.50 & 8.87 & 3 & 4 & Anastrepha serpentina & \\
\hline & $\begin{array}{c}02^{\circ} 05^{\prime} 39.3^{\prime \prime} \mathrm{S} \\
047^{\circ} 22^{\prime} 55.3^{\prime \prime} \mathrm{W}\end{array}$ & Citrus limettioides & 27 & 3.98 & 14 & 0.51 & 3.51 & & & & \\
\hline & & Citrus reticulata & 12 & 0.85 & 1 & 0.08 & 1.16 & & 1 & Anastrepha serpentina & \\
\hline \multirow[t]{3}{*}{ Irituia } & $\begin{array}{c}02^{\circ} 02^{\prime} 45.6^{\prime \prime} \mathrm{S} \\
047^{\circ} 22^{\prime} 08.2^{\prime \prime} \mathrm{W}\end{array}$ & Citrus sinensis & 39 & 7.11 & 90 & 2.30 & 12.64 & 9 & 4 & $\begin{array}{l}\text { Anastrepha obliqua } \\
\text { [ESALQENT000113-115] }\end{array}$ & $\begin{array}{l}\text { Opius bellus (18) } \\
\text { [ESALQENTT000116-125] } \\
\text { Asobara anastrephae (2) } \\
\text { [ESALQENT000126-127] }\end{array}$ \\
\hline & & Citrus medica & 19 & 1.16 & & & & & & & \\
\hline & & Citrus reticulata & 21 & 3.21 & 28 & 1.33 & 8.72 & 2 & $\begin{array}{l}2 \\
3 \\
\end{array}$ & $\begin{array}{c}\text { Anastrepha serpentina } \\
\text { Anastrepha sp. }\end{array}$ & \\
\hline \multirow[t]{12}{*}{ Mãe do Rio } & $\begin{array}{c}01^{\circ} 58^{\prime} 44.5^{\prime \prime}, \\
047^{\circ} 28^{\prime} 55.0^{\prime \prime} \mathrm{W}\end{array}$ & Citrus sinensis & 27 & 3.81 & 2 & 0.07 & 0.52 & & & & \\
\hline & & Citrus reticulata & 55 & 3.05 & 36 & 0.65 & 11.78 & 5 & 11 & Anastrepha serpentina & \\
\hline & $\begin{array}{c}02^{\circ} 00^{\prime} 38.0^{\prime \prime} \mathrm{S} \\
047^{\circ} 27^{\prime} 00.9^{\prime \prime} \mathrm{W}\end{array}$ & Citrus sinensis & 8 & 1.18 & & & & & & & \\
\hline & & Citrus reticulata & 6 & 0.53 & 3 & 0.50 & 5.60 & & & & \\
\hline & $\begin{array}{c}02^{\circ} 00^{\prime} 26.0^{\prime \prime} \mathrm{S}_{1} \\
047^{\circ} 26^{\prime} 42.2^{\prime \prime} \mathrm{W}\end{array}$ & Citrus sinensis & 18 & 2.18 & & & & & & & \\
\hline & & Citrus limettioides & 10 & 1.36 & 2 & 0.20 & 1.46 & & & & \\
\hline & & Citrus reticulata & 1 & 0.11 & & & & & & & \\
\hline & $\begin{array}{c}01^{\circ} 58^{\prime} 36.5^{\prime \prime} \mathrm{S} \\
047^{\circ} 29^{\prime} 16.9^{\prime \prime} \mathrm{W}\end{array}$ & Citrus sinensis & 3 & 1.48 & & & & & & & \\
\hline & $\begin{array}{c}02^{\circ} 04^{\prime} 08.5^{\prime \prime S}, \\
047^{\circ} 22^{\prime} 43.3^{\prime \prime} \mathrm{W}\end{array}$ & Citrus sinensis & 7 & 1.10 & & & & & & & \\
\hline & $\begin{array}{c}02^{\circ} 00^{\prime} 43.0^{\prime \prime} \mathrm{S} \\
047^{\circ} 30^{\prime} 18.6^{\prime \prime} \mathrm{W}\end{array}$ & Citrus sinensis & 6 & 0.66 & 4 & 0.66 & 6.01 & & & & \\
\hline & & Citrus medica & 18 & 1.63 & & & & & & & \\
\hline & & Citrus reticulata & 106 & 5.92 & 4 & 0.03 & 0.67 & & 1 & Anastrepha serpentina & \\
\hline $\begin{array}{l}\text { Aurora do } \\
\text { Pará }\end{array}$ & $\begin{array}{c}01^{\circ} 59^{\prime} 58.0^{\prime \prime} \mathrm{S}, \\
047^{\circ} 35^{\prime} 34.3^{\prime \prime} \mathrm{W}\end{array}$ & Citrus sinensis & 73 & 6.58 & & & & & & & \\
\hline TOTAL & & & 522 & 57.25 & 274 & & & 30 & 45 & & 20 \\
\hline
\end{tabular}

mombin (Spondias mombin L.) and coco plums (Chrysobalanus icaco L.), in the municipalities of Castanhal, Tomé-Açu, Belém and Ilha de Cotijuba, Baixo Amazonas, and on the Marajó Archipelago (Lemos et al. 2011a).

Economically, A. obliqua is an important species in Brazil (Zucchi 2007), while $A$. serpentina has not acquired this status. Fruit flies have become a major obstacle in the sustainable development of Amazonian fruit production, as they directly affect the quality of the final product, in addition to preventing products from satisfying the phytosanitary requirements of importing countries (Lemos et al. 2011a).

Oranges and mandarins were the most infested fruits in our samples (Table 1), which was expected, as they are highly susceptible to fruit fly infestation (Raga et al. 2004; Raga and Galdino 2017). Only citrons were not infested with fruit flies, probably because of their thick flavedo and albedo. The thickness of the flavedo and albedo layers of lemons, sour oranges (C. aurantium), Sicilian lemon (C. limon), and citrons (C. medica) are greater than those of sweet oranges. This hampers the survival of newly hatched larvae, which need to feed in an unfavorable environment until they reach the juice vesicles (Raga and Galdino 2017). In addition, the variation in fruit fly infestation could be attributed to fruit ripening stages, time and place of collection, seasonal variations, host diversity, and fruit availability (Malavasi et al. 1980). Infestation rates in oranges in Pará were considered low in comparison to those in other Brazilian regions (Lemos et al. 2011b; Castilho 2013). In another survey in Capitão Poço, average $A$. serpentina infestation rates of 2.28 puparia $\mathrm{kg}^{-1}$ and 0.3 puparia per fruit were reported in oranges (Castilho 2013), which were lower than those reported in here. 
Castilho (2013) and Lemos et al. (2011b) collected oranges in Capitão Poço and recovered only A. serpentina and the parasitoid Doryctobracon areolatus (Szépligeti). In addition to D. areolatus, O. bellus and Aganaspis pelleranoi (Brèthes) have been recorded in Pará (Lemos et al. 2011a). Our study is the first to record $A$. anastrephae in Pará. A new tritrophic relationship was also identified in Pará for the first time among oranges, $A$. obliqua, and the parasitoids $A$. anastrephae and $O$. bellus. The low number of parasitoids found in our survey was possibly due to low natural occurrence, our small sample size, and use of insecticides in nearby orchards.

The new species records reported in here add to the knowledge on the trophic relationships of the fruit fly complex in citrus orchards in Pará, and can inform future integrated fruit fly management programs in new agricultural frontiers.

\section{ACKNOWLEDGMENTS}

We wish to thank Conselho Nacional de Desenvolvimento Científico e Tecnológico (CNPq) for the junior postdoctoral (PDJ) and technological and industrial development (DTI) scholarships granted to the authors. We are also grateful to the $\mathrm{PhD}$ student Daniel Pereira Soares for support with the maps.

\section{REFERENCES}

Anuário Brasileiro de Fruticultura. 2018. Gazeta Santa Cruz, Santa Cruz do Sul, 88p.

Canal, N.A.; Zucchi, R.A. 2000. Parasitóides Braconidae. In: Malavasi, A.; Zucchi, R.A. (Ed.). Moscas-das-Frutas de Importância Econômica no Brasil - Conhecimento Básico e Aplicado. Holos, Ribeirão Preto, p.119-126.

Castilho, A.P. 2013. Índices de infestação de laranjas por Anastrepha serpentina (Weidemann) (Dip. Tephritidae) e parasitóides associados em diferentes sistemas de cultivo em Capitão Poço, Pará. Master's dissertation, Universidade Federal do Pará, Brazil, 83p. (http://ppgaa.propesp.ufpa.br/ARQUIVOS/dissertacoes/2012/ alison-pureza-castilho.pdf).

IBGE. 2019. Instituto Brasileiro de Geografia e Estatística. Produção Agrícola - Lavoura Permanente, 2018. (https://cidades.ibge. gov.br/brasil/pa/pesquisa/15/11863?tipo=ranking\&indicad or=11968). Accessed on 07 May 2020.

Lemos, W.P.; Araujo, S.C.A.; Silva, R.A.; Pereira, J.D.B. 2011 a. Conhecimento sobre moscas-das-frutas no estado do Pará. In: Silva, R.A.; Lemos, W.P.; Zucchi, R.A. (Eds.). Moscas-das-frutas na Amazônia Brasileira: Diversidade, Hospedeiros e Inimigos Naturais. Embrapa Amapá, Macapá, p.259-272.
Lemos, W.P.; Silva, R.A.; Araújo, S.C.A.; Oliveira, E.L.A.; Silva, W.R. 2011b. First record of Anastrepha serpentina (Wiedemann) (Diptera: Tephritidae) in citrus in Brazil. Neotropical Entomology, 40: 706-707.

Malavasi, A.; Morgante, J.S.; Zucchi, R.A. 1980. Biologia de moscas-das-frutas (Diptera: Tephritidae) I: Lista de hospedeiros e ocorrência. Revista Brasileira de Biologia, 40: 9-16.

Marinho, C.F.; Silva, R.A.; Zucchi, R.A. 2011. Chave de identificação de parasitóides Braconidae (Alysiinae e Opiinae) de larvas frugívoras na regiāo Amazônica. In: Silva, R.A.; Lemos, W.P.; Zucchi, R.A (Ed.). Moscas-das-frutas na Amazônia Brasileira: Diversidade, Hospedeiros e Inimigos Naturais. Embrapa Amapá, Macapá, p.91-101.

Parra, J.R.P.; Botelho, P.S.M.; Corrêa-Ferreira, B.S.; Bento, J.M.S. 2002. Controle biológico: terminologia. In: Parra, J.R.P.; Botelho, P.S.M.; Corrêa-Ferreira, B.S.; Bento, J.M.S. (Ed.). Controle Biológico no Brasil: Parasitoides e Predadores. Manole, São Paulo, p.1-16.

Raga, A.; Galdino, L.T. 2017. Sintomatologia do Ataque de Moscasdas-Frutas (Diptera: Tephritidae) em Citros. Instituto Biológico, Documento Técnico 33, 16p.

Raga, A.; Prestes, D.A.O.; Souza-Filho, M.F.; Sato, M.E.; Siloto, R.C.; Guimarães, J.A.; Zucchi, R.A. 2004. Fruit fly (Diptera: Tephritoidea) infestation in citrus in the State of São Paulo, Brazil. Neotropical Entomology, 33: 85-89.

Zucchi, R.A. 2007. Diversidad, distribución y hospederos del género Anastrepha en Brasil. In: Hernández-Ortiz, V. (Ed.). Moscas de la Fruta en Latinoamérica (Diptera: Tephritidae): Diversidad, Biologia y Manejo. S y G Editores, México, p.77-100.

Zucchi, R.A.; Moraes, R.C.B. 2008. Fruit flies in Brazil: Anastrepha species, their host plants and parasitoids. (www.lea.esalq.usp.br/ anastrepha/). Accessed on 21 Out 2020.

Zucchi, R.A.; Silva, R.A.; Deus, E.G. 2011 a. Espécies de Anastrepha e seus hospedeiros na Amazônia brasileira. In: Silva, R.A.; Lemos, W.P.; Zucchi, R.A (Ed.). Moscas-das-Frutas na Amazônia Brasileira: Diversidade, Hospedeiros e Inimigos Naturais. Macapá, Embrapa Amapá, Macapá, p.51-70.

Zucchi, R.A.; Uramoto, K.; Souza-Filho, M.F. 2011b. Chave ilustrada para espécies de Anastrepha da região amazônica. In: Silva, R.A.; Lemos, W.P.; Zucchi, R.A (Ed.). Moscas-das-Frutas na Amazônia Brasileira: Diversidade, Hospedeiros e Inimigos Naturais. Macapá, Embrapa Amapá, Macapá, p.71-90.

RECEIVED: $20 / 07 / 2020$

ACCEPTED: 20/10/2020

ASSOCIATE EDITOR: Juliana Hipólito de Sousa 